\title{
sensors
}

ISSN 1424-8220

(C) 2005 by MDPI

http://www.mdpi.org/sensors

\section{Development of a DNA Sensor Based on Alkanethiol Self- Assembled Monolayer-Modified Electrodes}

Óscar A. Loaiza, Susana Campuzano, María López-Berlanga, María Pedrero, and José M. Pingarrón*

Departamento de Química Analítica, Facultad de Ciencias Químicas, Universidad Complutense de Madrid, E-28040 - Madrid, Spain.

*To whom correspondence is to be addressed (E-mail: pingarro@quim.ucm.es)

Received: 26 January 2005 / Accepted: 3 July 2005 / Published: 14 November 2005

\begin{abstract}
An electrochemical DNA biosensor based on recognition of double or single stranded DNA (ds-DNA/ss-DNA) immobilised on a self-assembled modified gold electrode is presented for denaturalisation and hybridisation detection. DNA is covalently bond on a self assembled 3-mercaptopropionic acid monolayer by using water soluble N-3(dimethylaminopropyl)-N'ethylcarbodiimide hydrochloride (EDC) and Nhydroxisulfosuccinimide (NHSS) as linkers. The interaction between the immobilised DNA and methylene blue (MB) is investigated using square wave voltammetry (SWV). The increase or diminution of peak currents of the MB upon the hybridisation or denaturalisation event at the modified electrode surface is studied.
\end{abstract}

Key words: Calf thymus DNA; self-assembled monolayers; hybridization; denaturation; methylene blue. 


\section{Introduction}

In recent years there has been a considerable interest in the development of DNA sensors, due to its theoretical and practical significance in many fields. The detection of DNA hybridisation is of central importance in the diagnosis and treatment of genetic diseases, detection of infectious agents, industrial processing and reliable forensic analysis [1-5].

The analysis of specific gene sequences in the diagnostic laboratory is usually based on DNA hybridisation. Here, the target gene sequence is identified by a DNA probe able to form a doublestranded (ds) hybrid with its complementary nucleic acid with high efficiency and specificity [1].

Recently, a lot of progress has been made in the development of electrochemical DNAhybridisation biosensors (or genosensors). These biosensors rely on the conversion of the base-pair recognition event into a useful electrical signal. The sensing events on the electronic transducers are designed to alter the interfacial properties at the transducer/solution interface. Changes in the interfacial charge, capacitance, resistance, or mass thickness can occur upon the hybridisation of the analyte DNA with a probe nucleic acid and upon stimulation of the amplification route. Thus, various electronic transduction methods that follow such interfacial changes have been employed to probe DNA recognition events. These include electrochemical transduction means such as amperometry, faradaic impedance spectroscopy or chronopotentiometry, and microgravimetric, quartz crystal microbalance (QCM) measurements [6].

The DNA immobilization procedure on the electrode surface is a very important aspect since it influences the characterisation of the DNA probe, the sensor response, and its performance [7]. Thus, a key issue with a DNA biosensor is the accessibility and molecular orientation of the probe DNA, which requires a high degree of control over the immobilisation of the probe oligonucleotides. Selfassembled monolayers (SAMs) of alkanethiols, which have shown to provide molecular level control over the immobilisation of several types of biomolecules, have been used as active films on which DNA segments can be attached using covalent linkers [8]. 
Electrochemical DNA sensors based on the amperometric or voltammetric transduction of the formation of double stranded (ds) oligonucleotide-DNA complexes have been reported by following the direct electrical response of the ds-assembly [9], and the electrical response of the ds-assembly of the transition metal complexes [10] or dyes [11] that are intercalated or electrostatically attracted to the double stranded assembly. Many electroactive indicators such as cationic metal complexes [12], anticancer drugs [13] or organic dyes [14] have, thus, been employed in DNA hybridisation biosensors. The electrochemical response of these labels or indicators changes upon DNA hybridisation, usually increasing when the hybridisation process occurs due to an increase of the indicator concentration at the electrode surface.

Methylene blue (MB), an organic dye that belongs to the phenothiazine family, is a redox indicator, which, due to its interaction with the guanine bases in DNA, displays significantly different voltammetric signals in the presence of ss-DNA or ds-DNA modified electrodes [15]. The interaction between MB and DNA has, in fact, been studied by means of spectrophotometric and electrochemical methods $[8,16,17]$. So, Kelley et al $[17,18]$ investigated the charge transfer mechanism of Au electrodes covered with ds-DNA in the presence of MB concluding that MB show high affinity for immobilized DNA $\left(\mathrm{K} \approx 4 \times 10^{6} \mathrm{M}^{-1}\right)$ and that $\mathrm{MB}$ binding sites are localized mainly to the solutionaccessible periphery of the monolayer. It has also been reported that the peak potential of the MB square wave voltammetric signals at thiol terminated probe-modified AuEs was 10-15 mV more positive than the one at thiol terminated hybrid-modified AuEs [19].

When electrochemical genosensors are based on the use of commercially available Au disk or wire electrodes, an important drawback is found in the need of regeneration of a new, bare electrode surface after each measurement. Mechanical and chemical procedures used are tedious and time consuming. Thus, the main objective of this article is the development of a DNA electrochemical biosensor for detecting the hybridisation and denaturalisation events occurring at the surface of a gold electrode modified with a SAM of 3-mercaptopropionic acid (MPA) derivatised with EDC/ NHSS. 
The possibility of re-using the ss-DNA modified electrode for successive hybridisation/denaturalisation cycles will be checked.

\section{Experimental}

\subsection{Apparatus and electrodes}

Voltammetric measurements were carried out with an ECO Chemie Autolab PSTAT 10 potentiostat using the software package GPES 4.9 (General Purpose Electrochemical System). A PSelecta Digiterm 100 thermostatic bath, a P-Selecta ultrasonic bath, a IKAMAG ${ }^{\circledR}$ RET heating plate and a P-Selecta Agimatic magnetic stirrer were also used. Scanning electron micrographs were obtained with a JEOL JSM-6400 scanning microscope.

A Metrohm 6.1204.020 gold disk electrode (3-mm $\phi$ ) was used as electrode substrate to be coated with the modified MPA-SAM. A BAS MF-2063 Ag $|\mathrm{AgCl}| \mathrm{KCl} 3 \mathrm{M}$ reference electrode and a Pt wire counter electrode were also employed. A 10-mL glass electrochemical cell was used.

\subsection{Reagents and solutions}

Methylene blue (MB) was purchased from Sigma. Stock solutions of MB (1 mM) were prepared in a TE buffer (50 mM Tris- $\mathrm{HCl}, 20 \mathrm{mM} \mathrm{NaCl}, \mathrm{pH}$ 7.2). More dilute solutions were prepared by suitable dilution with the same buffer solution.

Single-stranded calf-thymus DNA (ss-DNA, lyophilized powder, Calatog No. D8899) and double-stranded calf-thymus DNA (ds-DNA, activated and lyophilized, Catalog No. D4522) were purchased from Sigma. DNA stock solutions (nominally $1000 \mathrm{mg} \mathrm{L}^{-1}$ ) were prepared in the TE buffer and kept frozen.

For the ss-DNA or ds-DNA immobilization onto the MPA-SAM, a $5 \mathrm{mM}$ Nhydroxysulfosuccinimide (NHSS) sodium salt (Fluka), and 2 mM 1-(3-dimethylaminopropyl)-3- 
ethylcarbodiimide (EDC) (Sigma), solution prepared in 0.05 M phosphate buffer (pH 7.0) was used as linker.

A $40 \mathrm{mM}$ mercaptopropionic acid (MPA) (Research Chemicals Ltd.) solution, prepared in a 75/25 \% v/v ethanol/water mixture, was employed for the formation of the monolayer.

Other solutions employed, prepared in deionized water, were: a $50 \mathrm{mM}$ tris(hydroxymethyl)aminomethane- $\mathrm{HCl}$ (Tris-HCl) (Aldrich) buffer solution containing $20 \mathrm{mM} \mathrm{NaCl}$ (Scharlau) (pH 7.2), and a $50 \mathrm{mM}$ sodium acetate (Sigma) buffer solution also containing $20 \mathrm{mM} \mathrm{NaCl}$, as supporting electrolytes; a $100 \mathrm{mM}$ Tris- $\mathrm{HCl}$ (Sigma) buffer solution containing $10 \mathrm{mM}$ EDTA (pH 8.0) as denaturalisation solution; a $30 \mathrm{mM}$ saline-sodium citrate buffer 2xSSC containing $300 \mathrm{mM}$ $\mathrm{NaCl}$ (Sigma) (pH 7.0) as hybridisation buffer; and 0.5 $\mathrm{M} \mathrm{H}_{2} \mathrm{SO}_{4}$ (Scharlau), 0.1 M NaOH (Sharlau), and $2 \mathrm{M} \mathrm{KOH} \mathrm{(Scharlau)} \mathrm{solutions} \mathrm{for} \mathrm{the} \mathrm{pretreatment} \mathrm{of} \mathrm{the} \mathrm{working} \mathrm{electrode.}$

All chemicals used were of analytical-reagent grade, and water was obtained from a Millipore Milli-Q purification system.

\subsection{Procedures}

\subsubsection{Pretreatment of the gold electrode $(A u E)$}

Before carrying out the deposition of the SAM, the gold disk electrode (AuE) was pretreated as follows. The AuE was polished with 3- $\mu \mathrm{m}$ diamond powder (BAS MF-2059) for 1 min. Then, it was sonicated in deionized water for $1 \mathrm{~min}$, immersed in an aqueous solution of $0.5 \mathrm{M} \mathrm{H}_{2} \mathrm{SO}_{4}$ where the potential was cycled between 0.0 and $+1.7 \mathrm{~V}$ (versus $\mathrm{Ag} / \mathrm{AgCl}$ ) at a scan rate of $100 \mathrm{mV} \mathrm{s}^{-1}$ for 10 consecutive scans [20]; then the electrode was rinsed with water and immersed in a $0.1 \mathrm{M} \mathrm{NaOH}$ solution for 15 min while applying a potential of $-0.8 \mathrm{~V}$ [21], rinsed with water, and then it was immersed for $1 \mathrm{~h}$ in a hot $2 \mathrm{M} \mathrm{KOH}$ solution. Next, the electrode was rinsed with water, immersed in concentrated $\mathrm{H}_{2} \mathrm{SO}_{4}$ for 10 min, rinsed with water, immersed in concentrated $\mathrm{HNO}_{3}$ (Scharlau) for 10 min, and rinsed again with deionized water. 


\subsubsection{Preparation of the MPA-modified AuE}

MPA-SAMs were formed by immersion of the clean AuE in a $40 \mathrm{mM}$ MPA solution in $\mathrm{EtOH} / \mathrm{H}_{2} \mathrm{O}(75 / 25 \mathrm{v} / \mathrm{v})$ for at least 15 hours. Then, the modified electrode was rinsed with deionized water. Under these conditions, a surface coverage of $\theta=0.95$ was calculated by electrochemical impedance spectroscopy, indicating a high electrode coverage by the alkanethiol SAM.

\subsubsection{DNA immobilization}

The MPA-modified AuE was activated by immersion for $1 \mathrm{~h}$ at room temperature (in dark condition) in a solution formed with $2 \mathrm{mM}$ EDC and $5 \mathrm{mM}$ NHSS. Subsequently, a $2.5 \mu \mathrm{L}$ drop of a $1000 \mathrm{mg} \mathrm{L}^{-1}$ ss-DNA or ds-DNA solution was deposited on the linker/MPA/AuE, let to dry at ambient temperature for at least $24 \mathrm{~h}$, and finally soaked in water for $2 \mathrm{~h}$ to remove unbound ss-DNA or dsDNA.

\subsubsection{MB accumulation onto the DNA/Linker/MPA/AuE}

The DNA-modified electrode was stirred in a $50 \mathrm{mM}$ Tris- $\mathrm{HCl}$ and $20 \mathrm{mM} \mathrm{NaCl}$ buffer solution (pH 7.2) containing $75 \mu \mathrm{M} \mathrm{MB}$ for 1 min at open circuit.

\subsubsection{Voltammetric transduction}

The DNA-modified electrode was then subsequently washed with the supporting electrolyte for $5 \mathrm{~s}$ and transferred into the blank buffer solution (MB-free $50 \mathrm{mM}$ Tris- $\mathrm{HCl}+20 \mathrm{mM} \mathrm{NaCl}, \mathrm{pH}$ 7.2) for the voltammetric measurements. The oxidation signal of the accumulated MB was measured by using square wave stripping voltammetry (SWSV) by scanning from -0.50 to $+0.10 \mathrm{~V}$ with an amplitude of $30 \mathrm{mV}$ and a step potential of $5 \mathrm{mV}$ at $100 \mathrm{~Hz}$, and by differential pulse stripping voltammetry (dp-SV) performed with an initial potential of $-0.5 \mathrm{~V}$ and an amplitude of $20 \mathrm{mV}$ at 20 
$\mathrm{mV} \mathrm{s}^{-1}$ scan rate. All experiments were conducted at room temperature (unless otherwise stated, $25 \pm$ $\left.0.5^{\circ} \mathrm{C}\right)$.

The electrode was electrochemically cleaned in-between stripping voltammetric measurements to assure the complete stripping of the previously accumulated redox label. This was accomplished by applying successive potential SW scans between -0.5 and $0.1 \mathrm{~V}$ during 5 min in the blank buffer solution.

\subsubsection{Denaturation}

For the denaturation of the ds-DNA immobilized onto the linker/MPA/AuE, the sensor was immersed in $5 \mathrm{~mL}$ of a $10 \mathrm{mN}$ Tris- $\mathrm{HCl}$ and $1 \mathrm{mM}$ EDTA buffer solution (pH 8.0) at $100{ }^{\circ} \mathrm{C}$ for $5 \mathrm{~min}$, followed by cooling in an ice bath [22].

\subsubsection{Hybridisation}

The hybridisation protocol was performed at $70^{\circ} \mathrm{C}$ by immersion of the denaturalised ds-DNAEDC-NHSS/MPA-AuE in $100 \mathrm{mg} \mathrm{L}^{-1}$ ss-DNA in the hybridisation buffer. The hybridisation time was $1 \mathrm{~h}$. Then the electrode was rinsed with deionized water to remove the unrecognised ss-DNA.

\section{Results and discussion}

Preliminary studies were carried out in order to select the optimum conditions for the detection of the structure (ss or ds) of DNA immobilised atop the electrode. The EDC/NHSS-MPA-AuE was prepared in all cases following the conditions described previously by our research group [23]. Then, $2.0 \mu \mathrm{g}$ of ss-DNA were immobilised atop the activated electrode as described in the Experimental Section. 
Firstly, the accumulation process of the redox indicator MB (Figure 1) on the ss-DNA modified electrode was studied.<smiles>CN=c1ccc2nc3ccc(N(C)C)cc3sc-2c1</smiles>

Figure 1. Structure of methylene blue.

Differential pulse (dp) and square wave (SW) voltammetric stripping signals for $20 \mu \mathrm{M} M B$ were compared (Figure 2), a much higher peak current being obtained when the stripping step was performed by SWV using a square wave amplitude of $30 \mathrm{mV}$ with a step potential of $5 \mathrm{mV}$ and a frequency of $100 \mathrm{~Hz}$ (scan rate, $500 \mathrm{mV} \mathrm{s}^{-1}$ ).

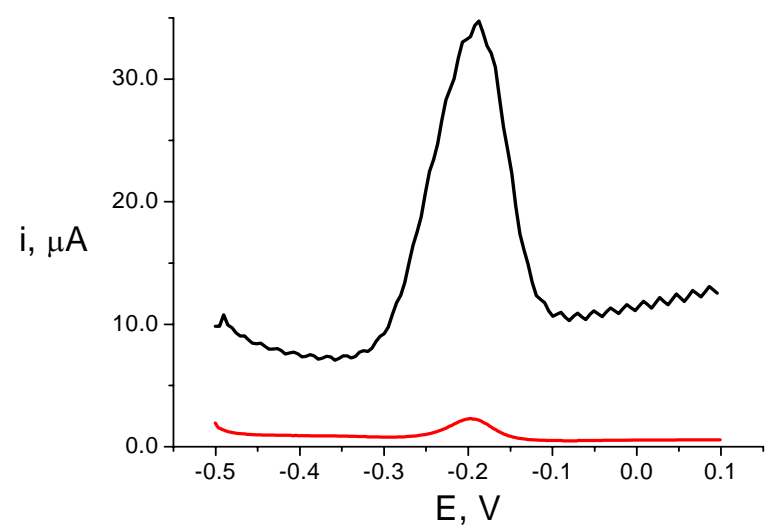

Figure 2. Stripping voltammograms obtained with the ss-DNA-EDC/NHSS-MPA-AuE after accumulation of MB. Supporting electrolyte: $50 \mathrm{mM}$ Tris-HCl, $20 \mathrm{mM} \mathrm{NaCl}$ (pH 7.2). Accumulation conditions: $[\mathrm{MB}]=20 \mu \mathrm{M}, \mathrm{t}_{\mathrm{acc}}=5 \mathrm{~min}$, open circuit. Measurement conditions: SWV $(-), \mathrm{E}_{\mathrm{sw}}=30$ $\mathrm{mV}, \mathrm{f}=100 \mathrm{~Hz}, \mathrm{v}=500 \mathrm{mV} \mathrm{s}^{-1}$, and DPV $(-) 20 \mathrm{mV} \mathrm{s}^{-1}, \Delta \mathrm{E}=20 \mathrm{mV}$. 
MB SW stripping currents obtained in both anodic and cathodic direction were also compared. In the conditions specified above, an oxidation peak current of $(2.6 \pm 0.6) \times 10^{-5} \mathrm{~A}(\mathrm{n}=5)$ at a peak potential of $-0.212 \mathrm{~V}$, and a reduction peak current of $(3 \pm 1) \times 10^{-5} \mathrm{~A}(\mathrm{n}=4)$ with $\mathrm{E}_{\mathrm{pc}}=-0.277 \mathrm{~V}$ were obtained. Taking into account the similar value of the peak currents, the better precision attained for the anodic measurements and the saving of time because no deareation is needed, the SW voltammetric oxidation signals of $\mathrm{MB}$, after its accumulation on the electrode surface, was taken as a criterion of selection in the optimisation of further working variables.

The influence of different buffer solutions both in the MB accumulation and in the stripping processes was also checked for a MB concentration in the accumulation solution of $20 \mu \mathrm{M}$ and an accumulation time of $5 \mathrm{~min}$ at open circuit. The buffer solutions considered were $50 \mathrm{mM}$ Tris- $\mathrm{HCl}(\mathrm{pH}$ 7.2) and $50 \mathrm{mM}$ acetate (pH 4.8), both of them containing $20 \mathrm{mM} \mathrm{NaCl}$. The obtained results show that a higher stripping peak current at a more negative peak potential was obtained when Tris-HCl (TE buffer solution) was used both in the accumulation and in the stripping processes, and therefore this buffer solution was chosen for further experiments.

The influence of experimental parameters such as MB accumulation time and concentration was also explored for optimum analytical performance. Thus, accumulation time was varied between $30 \mathrm{~s}$ and $5 \mathrm{~min}$ (Figure 3a), a higher peak current being obtained for $1 \mathrm{~min}$, which was chosen as accumulation time for further measurements. The decrease observed for accumulation times higher than 1 min indicates that this is the interval of time necessary to reach the saturation of the binding sites on the modified electrode. On the other hand, no significant differences were observed when the accumulation process was performed at open circuit or by application of any accumulation potential.

Regarding MB concentration (Figure 3b), the MB SW stripping peak current increased with this parameter in the 25 to $75 \mu \mathrm{M}$ range, levelling off for higher concentration values. Moreover, an increase in the peak width together with a lower reproducibility in the peak currents was observed for 
MB concentrations higher than $75 \mu \mathrm{M}$. As a consequence, this value was chosen as the optimum concentration for the redox label.
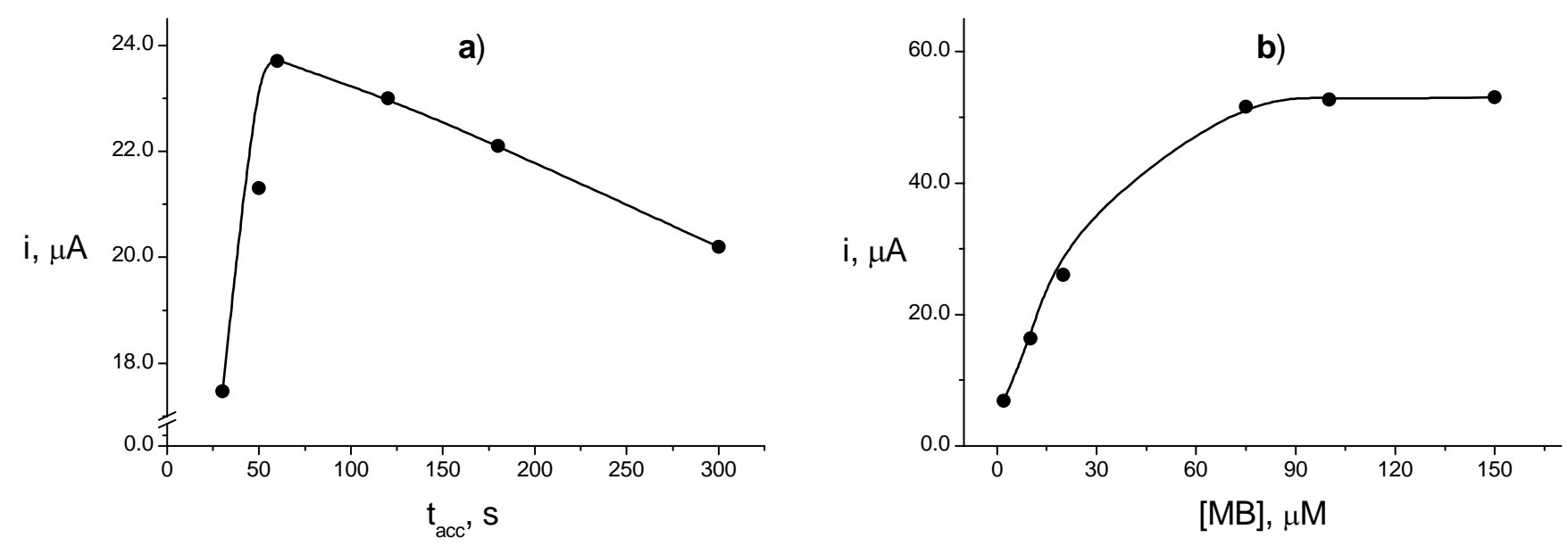

Figure 3. Effect of the accumulation time (a) and MB concentration (b) on the MB anodic stripping SW peak current at the ss-DNA-EDC/NHSS-MPA-AuE. Supporting electrolyte: $50 \mathrm{mM}$ Tris-HCl, 20 $\mathrm{mM} \mathrm{NaCl}\left(\mathrm{pH}\right.$ 7.2). Accumulation conditions: $[\mathrm{MB}]=20 \mu \mathrm{M}$ (a), $\mathrm{t}_{\mathrm{acc}}=1 \mathrm{~min}$ (b), open circuit. Measurement conditions: $\mathrm{SWV}, \mathrm{E}_{\mathrm{sw}}=30 \mathrm{mV}, \mathrm{f}=100 \mathrm{~Hz}, \mathrm{v}=500 \mathrm{mV} \mathrm{s}^{-1}$.

\subsection{Optimisation of the variables concerning the fabrication of the ss-DNA sensor}

Experimental variables such as the effect of the DNA drying time atop the activated electrode, and the amount of probe DNA immobilised were evaluated. Concerning the former parameter, the effect of the drying time in the range 1-72 $\mathrm{h}$ on the MB SW stripping peak currents was checked. At least $24 \mathrm{~h}$ were needed to assure an adequate covalent bonding between carboxyl groups in the MPAAuE and deoxyguanosine residues of DNA, where EDC and NHSS are used as coupling reagents [24]. Moreover, when ss-DNA was immobilised by immersion of the EDC/NHSS-MPA activated electrode in $2.5 \mathrm{~mL}$ of a $200 \mathrm{mg} \mathrm{L}^{-1}$ ss-DNA solution in TE buffer for $24 \mathrm{~h}$ a lower response (10-fold) for MB was obtained, thus indicating that this immobilisation procedure yielded a poorer covalent bonding of DNA to the activated electrode. 
On the other hand, the probe amount immobilised in the ss-DNA-EDC/NHSS-MPA-AuE greatly affected the MB binding process onto the electrode surface. As it can be seen in Figure 4, the redox label SW stripping peak current increased linearly $\left(\mathrm{i}(\mu \mathrm{A})=(2.0 \pm 0.2) \times 10^{-5} \mu \mathrm{g}\right.$ ss-DNA + $\left.(1.7 \pm 0.3) \times 10^{-5} ; r=0.989\right)$ in the $0-2.5 \mu \mathrm{g}$ ss-DNA range, indicating that full binding sites coverage by MB could be achieved. Moreover, this fact could give the possibility of quantifying the amount of ssDNA contained in unknown samples. Above this value, the stripping signal decreased sharply probably due to the blocking of the electrode surface by the great amount of immobilised DNA. Thus, $2.5 \mu \mathrm{g}$ was the amount of ss-DNA selected as optimum for the fabrication of the ss-DNA-EDC/NHSSMPA-AuE.

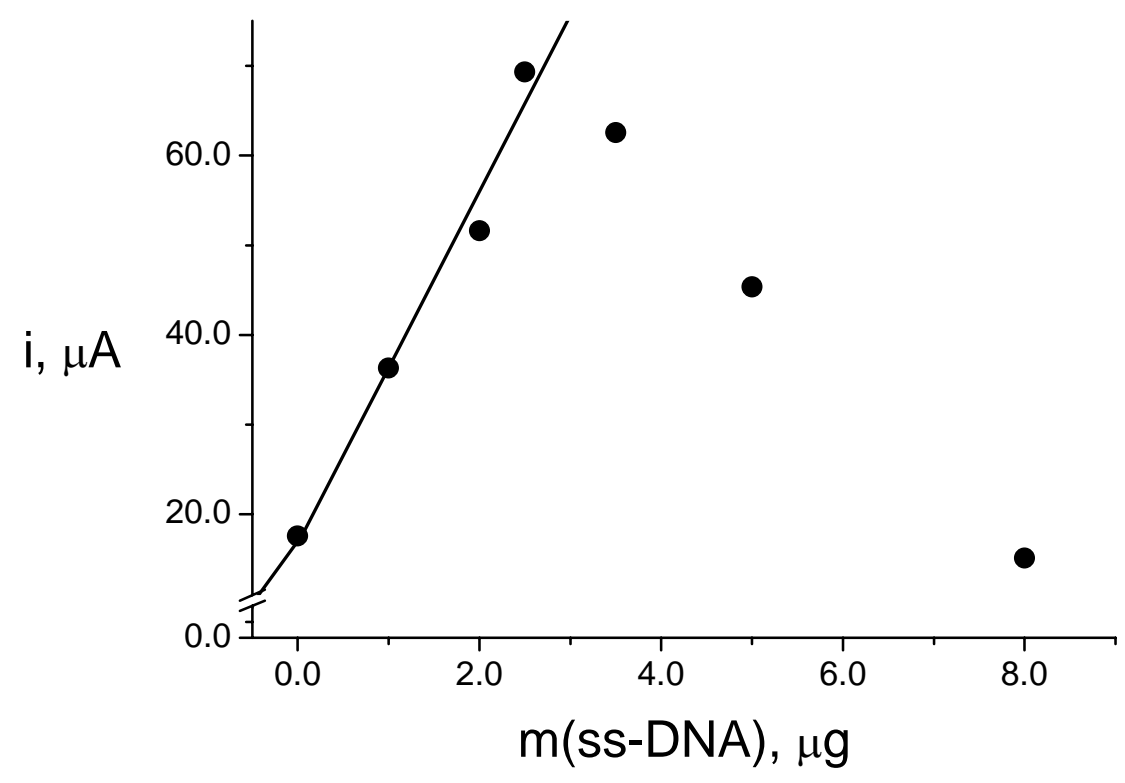

Figure 4. Effect of the DNA probe amount used in the ss-DNA immobilisation process on the MB anodic stripping SW peak current at the ss-DNA-EDC/NHSS-MPA-AuE. Supporting electrolyte: 50 $\mathrm{mM}$ Tris-HCl, $20 \mathrm{mM} \mathrm{NaCl}$ ( $\mathrm{pH}$ 7.2). Immobilization conditions: $t_{\text {drying }}=24 \mathrm{~h}$. Accumulation conditions: $[\mathrm{MB}]=75 \mu \mathrm{M}, \mathrm{t}_{\mathrm{acc}}=1 \mathrm{~min}$, open circuit. Measurement conditions: SWV $(-), \mathrm{E}_{\mathrm{sw}}=30$ $\mathrm{mV}, \mathrm{f}=100 \mathrm{~Hz}, \mathrm{v}=500 \mathrm{mV} \mathrm{s}^{-1}$. 


\subsection{Characteristics of the DNA-modified electrode}

Firstly, the magnitudes of stripping peak currents after accumulation of MB at each stage in the fabrication of an ss-DNA-EDC/NHSS-MPA-AuE were recorded and compared with the signal obtained at the bare AuE. As expected, the MPA-AuE exhibited a negligible response for MB. The activation of this monolayer with EDC and NHSS (EDC/NHSS-MPA-AuE) resulted in an increase of the MB peak current, which could be due to the bonding of MB to the linker through its amine groups. Nevertheless, the current obtained was still approximately half than that measured at the bare AuE. Only after further immobilization of ss-DNA onto the activated MPA-AuE (ss-DNA-EDC/NHSSMPA-AuE), a large increase in the MB stripping peak current was obtained due to the higher affinity of $\mathrm{MB}$ for the DNA guanine bases. These results were also compared with the stripping signals obtained at an ss-DNA-MPA-AuE, which were even slightly lower than those obtained at the EDC/NHSS-MPA-AuE. This clearly shows the importance of the previous activation of the MPA monolayer with the linker compounds for a correct design of the biosensor. In the absence of activation, DNA is just adsorbed onto the MPA-AuE and it is easily washed out during the washing step.

Figure 5 shows the SW stripping voltammograms of MB obtained at an ss-DNA-EDC/NHSSMPA-AuE (blue line) and at a ds-DNA-EDC/NHSS-MPA-AuE (red line) where $2.5 \mu \mathrm{g}$ of ds-DNA had been immobilised atop the activated electrode in the same experimental conditions as ss-DNA in the previous experiments. Although it has been reported that intercalation of MB after hybridisation produced an increase of the MB peak current [24], there are several authors stating that MB binds to the free guanine bases in DNA resulting in a higher MB accumulation at ss-DNA modified electrode surfaces [8, 25, 26]. Results displayed in Figure 5 show that the MB stripping signal was significantly lower at the ds-DNA-modified electrode than at the ss-DNA-modified electrode. These results indicate that although there is a voltammetric signal due to MB intercalation in ds-DNA, this is smaller when 
compared to the signal from the direct interaction of MB with the higher number of free guanine bases in ss-DNA.

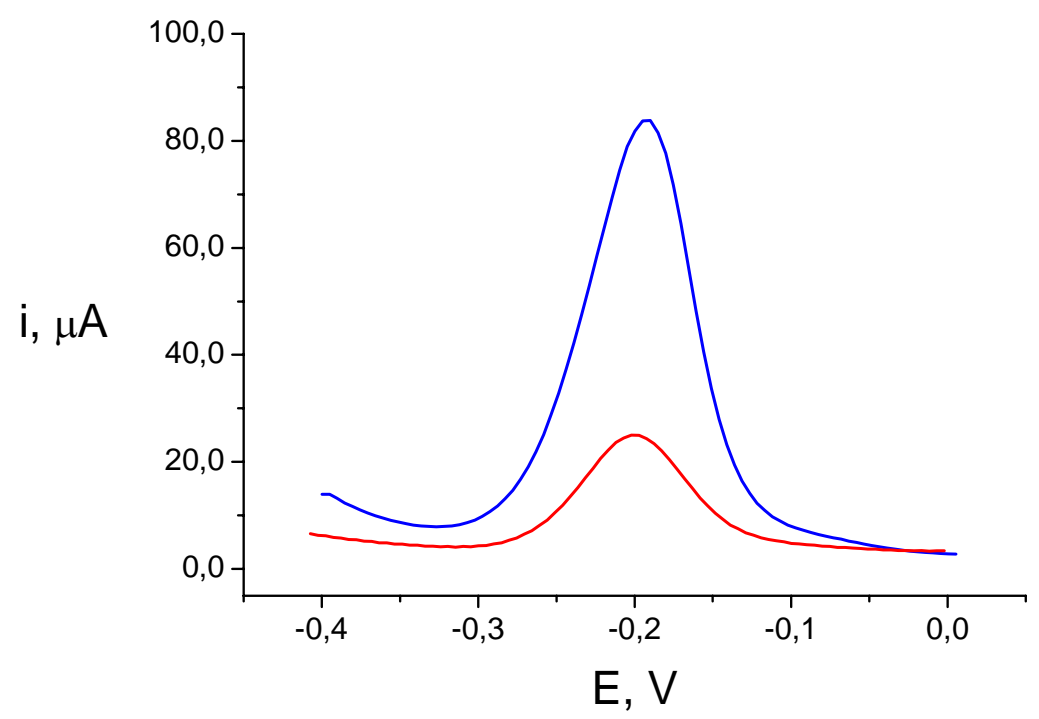

Figure 5. Stripping voltammograms obtained with the ss-DNA-EDC/NHSS-MPA-AuE $(-)$ and with the ds-DNA-EDC/NHSS-MPA-AuE (-) after accumulation of MB. Supporting electrolyte: $50 \mathrm{mM}$ Tris-HCl, $20 \mathrm{mM} \mathrm{NaCl}(\mathrm{pH}$ 7.2). Immobilization conditions: $2.5 \mu \mathrm{g}$ DNA, 24 h drying time. Accumulation conditions: $[\mathrm{MB}]=75 \mu \mathrm{M}, \mathrm{t}_{\mathrm{acc}}=1 \mathrm{~min}$, open circuit. Measurement conditions: SWV, $E_{s w}=30 \mathrm{mV}, \mathrm{f}=100 \mathrm{~Hz}, \mathrm{v}=500 \mathrm{mV} \mathrm{s}^{-1}$.

Figure 6 shows scanning electron micrographs of an ss-DNA-EDC/NHSS-MPA-AuE without (a) and after (b) MB accumulation. The modified electrode shows the presence of circular grooves, which are probably due to the mechanical polishing to which AuE disk electrodes are usually subjected after their fabrication process. When MB is accumulated at the modified electrode, a more dense and homogeneous coverage is observed, the grooves not being appreciated. The presence of MB was also demonstrated by elemental analysis of these electrodes surfaces, where the presence of $\mathrm{N}$ was only detected at the electrode subjected to the accumulation process. 

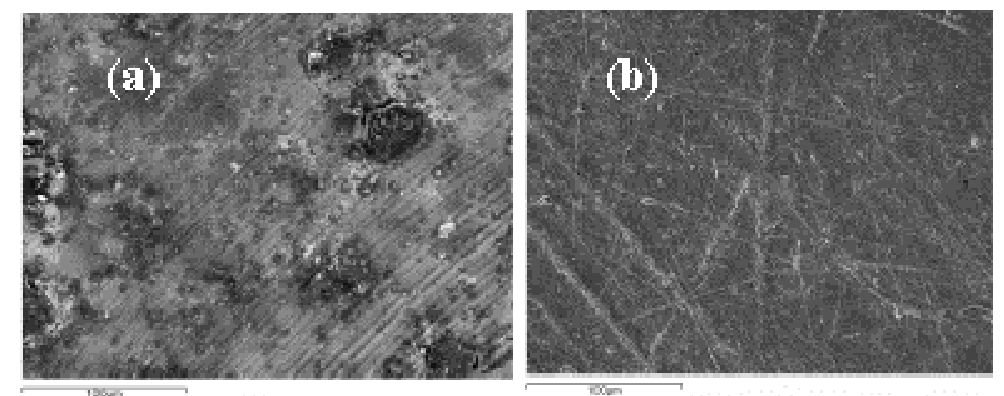

Figure 6. Scanning electron micrographs obtained for an ss-DNA-EDC/NHSS-MPA-AuE before (a) and after (b) accumulation of MB. Immobilization conditions: $2.5 \mu \mathrm{g}$ DNA, 24 h drying time. Accumulation conditions (b): $[\mathrm{MB}]=75 \mu \mathrm{M}, \mathrm{t}_{\mathrm{acc}}=1 \mathrm{~min}$, open circuit.

Finally, and as a previous step before studying the DNA hybridization and denaturation processes at the developed sensors surface, two aspects regarding the stability of the ss-DNA and the ds-DNA-EDC/NHSS-MPA-AuEs were evaluated.

Firstly, the repeatability of the electrochemical responses was checked. Thus, five successive SW-SV $75 \mu \mathrm{M}$ MB measurements were performed at the DNA-modified electrodes. The electrode was cleaned in-between measurements as described in Section 2.3.5. In these conditions, relative standard deviations (RSDs) of $6.2 \%$ and $7.5 \%$ were obtained for the stripping peak currents of MB at the ssDNA-EDC/NHSS-MPA-AuE and the ds-DNA-EDC/NHSS-MPA-AuE, respectively. These results indicate a good stability of both, ss-DNA and ds-DNA when immobilized atop the SAM-modified electrode.

Secondly, the reproducibility of the DNA sensors preparation procedure was tested. Results from MB stripping peak currents at five ss-DNA-modified electrodes constructed in the same manner yielded a RSD of $5.3 \%$, while for five ds-DNA modified electrodes a RSD of $6.0 \%$ was obtained. 
These results demonstrated that the fabrication procedure of the DNA-EDC/NHSS-MPA-AuEs was reliable, thus allowing reproducible electroanalytical responses to be obtained with different sensors.

\subsection{Denaturation and hybridization of immobilized DNA: preliminary studies}

The detection of denaturation and hybridization events was accomplished by using the oxidation signals obtained after the accumulation process of methylene blue at the DNA sensors. This was possible because, as demonstrated before (Figure 5), the electroactivity of this label led to discrimination of ss-DNA or ds-DNA.

Firstly, the experimental conditions for the denaturation process of ds-DNA were optimized. Most of ds-DNA denaturation procedures found in literature are carried out in solution, then immobilizing the obtained ss-DNA at the electrochemical sensor. Three denaturation procedures were compared. The first one, based on that used by Gu et al. [24], consisted on immersing a 1000 ppm dsDNA stock solution in TE buffer in a water bath, heating at $100{ }^{\circ} \mathrm{C}$ for $10 \mathrm{~min}$, and then rapidly cooling in an ice-water bath. When the thus obtained single stranded DNA was immobilized at an activated MPA-AuE under the optimized conditions commented above, no increase was observed for the MB peak current if compared to that obtained with a ds-DNA-EDC/NHSS-MPA-AuE, even when the heat-denaturation process was carried out for $1 \mathrm{~h}$. The second denaturation procedure tested was based on that followed by He et al. [27] and consisted on adding $75 \mu \mathrm{L}$ of a $2 \mathrm{M} \mathrm{NaOH}$ and $1.5 \mathrm{M}$ $\mathrm{NaCl}$ solution to $300 \mu \mathrm{L}$ of the $1000 \mathrm{ppm}$ ds-DNA stock solution. After $1 \mathrm{~h}$, the solution was heated in a water bath at $100{ }^{\circ} \mathrm{C}$ for $10 \mathrm{~min}$, rapidly cooling it afterwards in an ice-bath. When the thus denaturalized DNA was immobilized atop an activated MPA-AuE an increase of around $110 \%$ in the MB voltammetric signal was obtained if compared to that observed at a ds-DNA-EDC/NHSS-MPAAuE, indicating that denaturation of ds-DNA occurred to some extent. However, a very low reproducibility was found when the experiment was carried out several times. Finally, we checked the possibility of denaturalizing the ds-DNA, which had previously been immobilized at an activated 
MPA-AuE. This procedure could give the possibility to obtain a reusable DNA sensor, for successive hybridization/denaturation cycles and thus, in the analysis of various DNA samples. The ds-DNAEDC/NHSS-MPA-AuE was immersed in a $10 \mathrm{mM}$ Tris-HCl and $1 \mathrm{mM}$ EDTA buffer solution (pH 8.0) at $100{ }^{\circ} \mathrm{C}$ for $5 \mathrm{~min}$. An increase in the $\mathrm{MB}$ peak current of $(350 \pm 10) \%$ was obtained at the denaturalised-ds-DNA-EDC/NHSS-MPA-AuE. This increase was shown to be reproducible as the denaturation process was repeated, and it kept after storing the denaturalised electrode at $4{ }^{\circ} \mathrm{C}$ in dry conditions for $24 \mathrm{~h}$. Furthermore, when temperatures lower than $100{ }^{\circ} \mathrm{C}$ were used, denaturation was not reproducible, and the voltammetric signal continuously decreased, probably as a consequence of re-hybridisation at the electrode surface. Therefore, it could be concluded that no significant rehybridisation occurred after application of the denaturation procedure.

On the other hand, the possibility of SAM removal from the electrode when the denaturation procedure was applied was also checked. MPA-modified electrodes subjected to this procedure showed no significant increase for the MB response when compared to the untreated modified electrode, thus indicating that no SAM peeling off occurred.

Regarding the hybridization process, two procedures were also tested. The first one consisted on pippetting onto the denaturalized-ds-DNA-EDC/NHSS-MPA-AuE $20 \mu \mathrm{L}$ of $20 \mathrm{mM}$ TE buffer solution containing 100 ppm of ss-DNA and air-drying for $30 \mathrm{~min}$ [8], while in the second procedure the denaturalized-ds-DNA-EDC/NHSS-MPA-AuE was further hybridized by immersion in a 100 ppm solution of ss-DNA in $0.3 \mathrm{M} \mathrm{NaCl}$ and $30 \mathrm{mM}$ sodium citrate buffer (2xSSC buffer, $\mathrm{pH} 7.0$ ) with stirring for $1 \mathrm{~h}$ at $70{ }^{\circ} \mathrm{C}$ and then cooling gradually to room temperature [24]. The observation of the decrease in the MB stripping peak current was only possible by using the latter procedure, thus demonstrating the suitability of the developed sensor for the detection of the hybridization event.

Currently, studies on the optimization of the hybridization process and detection of point mutations toward the possibility of constructing sensors to detect pathogen microorganisms, based on the reported design, are being carried out in our lab. 


\section{Conclusions}

The possibility of constructing DNA biosensors using gold electrodes modified with MPASAMs derivatized with EDC and NHSS, and methylene blue as electrochemical label is demonstrated. Under the optimized label SW voltammetric measurement and ss-DNA probe immobilization conditions, both denaturation and hybridization events can be detected by using the oxidation signals obtained after accumulation of MB on the DNA sensors. The reproducibility and increase of the magnitude of the MB peak current after DNA denaturation, directly at the electrode surface, are highly promising features towards the preparation of reusable DNA sensors.

\section{Acknowledgements}

The financial support of the Ministerio de Ciencia y Tecnología, Dirección General de Investigación, Project BQU2003-00365 is gratefully acknowledged. Oscar A. Loaiza acknowledges a pre-PhD fellowship of the Universidad Complutense de Madrid. The collaboration of the "Centro de Microscopía Electrónica Luis Bru” is also acknowledged.

\section{References and Notes}

1. Lucarelli, F.; Marrazza, G.; Turner A. P. F.; Mascini, M. Carbon and gold electrodes as electrochemical transducers for DNA hybridisation sensors. Biosensors and Bioelectronics 2004, 19, 515-530.

2. Gau, J., Jr.; Lan H. E.; Dunn, B.; Chih-Ming, H.; Woo, J. C. S. A MEMS based amperometric detector for E. Coli bacteria using self-assembled monolayers. Biosensors and Bioelectronics 2004, 16, 745-755. 
3. Wang, J.; Lin, G. D.; Merkoci, A. Electrochemical coding technology for simultaneous detection of multiple DNA targets. J. Am. Chem. Soc. 2003, 125, 3214-3215.

4. Hölzel, R.; Gajovic-Eichelmann, N.; Bier, F. F. Oriented and Vectorial immobilization of linear M13 dsDNA between interdigitated electrodes-towards single molecule DNA nanostructures. Biosensors and Bioelectronics 2003, 18, 555-564.

5. Vercoutere, W. and Akeson, M. Biosensors for DNA sequence detection. Curr. Op. Chem. Biol. 2002, 6, 816-822.

6. Brajter-Toth, A.; Chambers, J. Q. In Electroanalytical Methods for Biological Materials; Marcel Dekker, Inc., Ed.; Basel: New York, 2002; Chapter 3, p 43-49.

7. Chiorcea Paquim, A. M.; Diculescu, V. C.; Oretskaya, T. S.; Oliveira Brett, A. M. AFM and electroanalytical studies of synthetic oligonucleotide hybridization. Biosensors and Bioelectronics 2004, 20, 933-944.

8. Kerman, K.; Ozhan, D.; Kara, P.; Meric, B.; Gooding, J. J.; Ozsoz, M. Voltammetric determination of DNA hybridization using methylene blue and self-assembled alkanethiol monolayer on gold electrodes. Anal. Chim. Acta 2002, 462, 39-47.

9. Wang, J.; Palecek, E.; Nielsen, P. E.; Rivas, G.; Cai, X.; Shiraishi, H.; Doutha, N.; Luo, D. B.; Farias, P. A. M. Peptide Nucleic Acid Probes for Sequence-Specific DNA Biosensors. J. Am. Chem. Soc. 1996, 118, 7667-7670.

10. Hashimoto, K., Ito, K., Ishimori, Y. Sequence-Specific Gene Detection with a Gold Electrode Modified with DNA Probes and an Electrochemically Active Dye. Anal. Chem. 1994, 66, 38303833.

11. Millan, K. M., Saraullo, A., Mikkelsen, S. R. Voltammetric DNA Biosensor for Cystic Fibrosis Based on a Modified Carbon Paste Electrode. Anal. Chem. 1994, 66, 2943-2948.

12. Erdem, A.; Kerman, K.; Meric, D.; Akarca, U. S.; Ozsoz, M. DNA electrochemical biosensor for the detection of short DNA sequences related to the hepatitis B virus. Electroanalysis 1999, 11(8), 586-588. 
13. Erdem, A.; Ozsoz, M. Interaction of the anticancer drug epirubicin with DNA. Anal. Chim. Acta. 2001, 437, 107-114.

14. Yan, F.; Erdem, A.; Meric, B.; Kerman, K.; Ozsoz, M.; Sadik O. A. Electrochemical DNA biosensor for the detection of specific gene related to Microcystis species. Electrochem. Commun. 2001, 3, 224-228.

15. Erdem, A.; Kerman, K.; Meric, B.; Akarca, U. S.; Ozsoz M. Novel hybridization indicator methylene blue for the electrochemical detection of short DNA sequences related to the hepatitis B virus. Anal. Chim. Acta 2000, 422, 139-149.

16. Rohs, R.; Sklenar, H. Methylene blue binding to DNA with alternating AT base sequence: minor groove binding is favored by intercalation. J. Biomol. Struct. Dyn. 2004, 21(5), 699-711.

17. Kelley, O. S. and Barton, K. J. Electrochemistry of methylene blue bond to a DNA-modified electrode. Bioconj. Chem. 1997, 8, 31-37.

18. Taft, B.J.; O’Keefe, M.; Fourkas, J.T.; Kelley, S.O. Engineering DNA-electrode connectivities: manipulation of linker length and structure. Anal. Chim. Acta 2003, 496, 81-91.

19. Tani, A.; Thomson, A. J., Butt, J. N. Methylene blue as an electrochemical discriminator of singleand double-stranded oligonucleotides immobilized on gold substrates. Analyst 2001, 126, 17561759.

20. Zhao, Y.D.; Pang, D.W.; Wang, Z.L.; Cheng, J.K.; Qi, Y.P. DNA-modified electrodes. Part 2. Electrochemical characterization of gold electrodes modified with DNA. J. Electroanal. Chem. 1997, 431, 203-209.

21. Munakata, H.; Kuwabata, S.; Ohko, Y.; Yoneyama, H. Spatial distribution of domains in binary self-assembled monolayers of thiols having different lengths. J. Electroanal. Chem. 2001, 496, 2936.

22. Pang, D. W.; Zhang, M.; Wang, Z. L.; Qi, Y. P.; Cheng, J. K.; Liu Z. Y. Modification of glassy carbon and gold electrodes with DNA. J. Electroanal. Chem. 1996, 403, 183-188. 
23. Campuzano, S.; Gálvez, R.; Pedrero, M.; Manuel de Villena, F. J.; Pingarrón, J. M.; Preparation, characterization and application of alkanethiol self-assembled monolayers modified with TTF and glucose oxidase at a gold disk electrode. J. Electroanal. Chem. 2002, 526, 92-100.

24. Gu, J.; Lu, X.; Ju, H. DNA sensor for recognition of native yeast DNA sequence with methylene blue as an electrochemical hybridisation indicator. Electroanalysis 2002, 14(13), 949-954.

25. Ozkan, D.; Kara, P.; Kerman, K.; Meric, B.; Erdem, A.; Jelen, F.; Nielsen P.E.; Ozsoz, M. DNA and PNA sensing on mercury and carbon electrodes by using methylene blue as an electrochemical label. Bioelectrochemistry 2002, 58, 119-126.

26. Kara, P.; Kerman, K.; Ozkan, D.; Meric, B.; Erdem, A.; Ozkan, Z.; Ozsoz, M. Electrochemical genosensor for the detection of interaction between methylene blue and DNA. Electrochem. Commun. 2002, 4, 705-709.

27. He, F.; Liu, S. Detection of $P$. aeruginosa using nano-structured electrode-separated piezoelectric DNA biosensor. Talanta 2004, 62, 271-277.

(C) 2005 by MDPI (http://www.mdpi.org). Reproduction is permitted for noncommercial purposes. 